Vol 2. No 2. Agustus 2018

ISSN 2580-5029

\title{
VARIASI MORFOLOGI DAN KEMELIMPAHAN Donax faba (BIVALVIA: DONACIDAE) DI PANTAI TENGKET BANGKALAN MADURA
}

\author{
Dianah Filzan Alyani', Reni Ambarwati 1* \\ ${ }^{1}$ Universitas Negeri Surabaya, Surabaya, Indonesia \\ *Email: reniambarwati@unesa.ac.id
}

\begin{abstract}
Donax clams are important in taxonomic studies because they have many variations. The purposes of this study were to evaluate the morphological variations and the abundance of Donax clams; to analyze the habitat profiles of Donax clams at Tengket Bangkalan Madura Beach. The sample of clams were taken by belt transect method. The habitat profile was studied based on the substrate type, water acidity, substrate acidity, salinity and the temperature of water. The data was analyzed descriptive quantitatively. The results showed that in Beach Tengket Madura found Donax faba which had 15 types. The most abundant variety was creamy with brown spots on the ventral and purplish white with brown spots. The profile of the habitat of D. faba in Tengket Beach was medium sandy substrate with water $p H 6.7$ and substrate $p H$ 7, salinity 32.6-32.8\%, and temperature $32^{\circ} \mathrm{C}$.
\end{abstract}

Keywords: Donax clams, morphological variations, abundance, profile habitat

\section{ABSTRAK}

Kerang Donax penting dalam kajian taksonomi dikarenakan memiliki banyak variasi. Tujuan penelitian ini adalah mengevaluasi variasi morfologi dan kemelimpahan kerang Donax; serta menganalisis profil habitat kerang Donax di Pantai Tengket Bangkalan Madura. Sampel kerang diambil dengan metode belt transect . Profil habitat yang dikaji adalah tipe substrat, $\mathrm{pH}$ air, $\mathrm{pH}$ substrat, salinitas dan suhu. Data hasil penelitian yang diperoleh kemudian dianalisis secara deskriptif kuantitatif. Hasil penelitian menunjukkan bahwa di Pantai Tengket Madura ditemukan kerang Donax faba yang memiliki 15 tipe. Variasi yang paling melimpah adalah krem dengan bercak cokelat di bagian ventral dan paling sedikit adalah putih keunguan dengan bercak cokelat. Profil habitat $D$. faba di Pantai Tengket adalah substrat bertipe pasir sedang dengan $\mathrm{pH}$ air 6,7 dan pH substrat 7, salinitas $32,6-32,8 \%$, serta suhu $32^{\circ} \mathrm{C}$.

Kata Kunci: kerang Donax, variasi morfologi, kemelimpahan, profil habitat

\section{PENDAHULUAN}

Indonesia memiliki kekayaan dan sumber daya laut yang tinggi, salah satunya adalah kelompok kerangkerangan. Salah satu famili dari Kelas
Bivalvia yang belum banyak diteliti, namun memiliki potensi untuk dimanfaatkan adalah kerang dari Famili Donacidae. Donacidae merupakan jenis bivalvia yang berada di daerah intertidal 
dan jumlah terbesar ditemukan pada daerah pasang surut air laut. Kerang dari famili ini misalnya dari genus Donax merupakan komponen penting makrofauna di daerah intertidal dari pantai berpasir (Zeichen et al., 2002).

Distribusi genus Donax di pantai berpasir ditentukan oleh profil habitat yang meliputi tekstur substrat, suhu, dan pasang surut (Singh et al., 2011). Dharma (2005) melaporkan beberapa anggota Donax di daerah tropis antara lain Donax faba.

Donax faba dan D. cuneatus tidak hanya penting secara ekologis, namun juga dalam kajian taksonomi. Kerang ini memiliki keunikan yang dapat dilihat dari adanya variasi morfologi cangkang meliputi warna, pola, maupun morfometrinya. Beberapa penelitian sebelumnya menunjukkan bahwa kerang Donax memiliki berbagai macam variasi. Smith (1975) telah melaporkan adanya variasi morfologi pada D. faba di Tanzania, ditemukan 14 variasi yang ditinjau dari perbedaan pola dan warna, Tan dan Woo (2010) menyatakan bahwa terdapat dua spesies kerang Donax di Singapura yaitu D. cuneatus dan D. faba. Tan dan Low (2013) juga menjelaskan bahwa D. cuneatus dan D. faba memiliki warna dan pola yang bervariasi. Ambarwati dan Faizah (2017) melaporkan dan mendeskripsikan 12 variasi pola dan warna yang berbeda pada kerang D. cuneatus dan D. faba.

Penelitian sebelumnya Subono (2016) melaporkan struktur populasi kepiting Tentara di Pantai Pangpajung, Bangkalan Madura. Selain itu, Ambarwati dan Faizah (2017) juga menemukan populasi D. cuneatus dan D. faba di Pantai Nepa Sampang Madura. Hal ini membuktikan bahwa beberapa Pantai di Bangkalan memiliki keanekaragaman biota laut yang tinggi. Pantai Tengket Bangkalan Madura merupakan salah satu habitat kerang Donax. Akan tetapi, informasi lebih dalam mengenai variasi morfologi dan kemelimpahan kerang Donax di Pantai Tengket belum didapatkan, sehingga perlu dilakukan penelitian untuk menggali informasi mengenai variasi morfologi, kemelimpahan dan profil habitat kerang Donax di Pantai Tengket Bangkalan Madura.

\section{METODE}

Penelitian ini dilaksanakan pada bulan November 2017 hingga April 2018. Lokasi penelitian dan pengambilan sampel kerang Donax adalah di Pantai Tengket Bangkalan Madura. Metode dalam penelitian ini ialah metode 
observasional in situ. Identifikasi dan pengamatan variasi morfologi dilakukan di Laboratorium Taksonomi jurusan Biologi FMIPA Universitas Negeri Surabaya.

Teknik sampling menggunakan metode belt transect. Pada lokasi ditentukan tiga stasiun yang terdiri atas dua garis transek. Setiap transek tersapat 10 plot berukuran 1x1 m menyebar secara horizontal. Kerang Donax di setiap plot diambil mulai yang ada di permukaan ataupun yang berada dalam substrat sampai kedalaman $10 \mathrm{~cm}$. Kerang Donax disortir dan dihitung pada setiap plotnya. Kemelimpahan dianalisis dengan rumus kemelimpahan relatif (KR\%):

$$
\mathrm{KRi}=\left(\frac{n i}{N}\right) \times 100 \%
$$

\section{Keterangan:}

$$
\begin{array}{ll}
\mathrm{Kri} & =\text { kelimpahan setiap jenis } \\
\mathrm{Ni} & =\text { jumlah individu jenis ke-I } \\
\mathrm{N} & =\text { total individu yang ditemukan }
\end{array}
$$

Pengukuran parameter profil habitat meliputi tipe substrat, $\mathrm{pH}$ substrat, salinitas, dan suhu. Substrat Pantai Tengket diambil sebanyak \pm 200 gram dan diayak menggunakan mesh ayakan ukuran 35, 40, 80, 140, dan 325. pH substrat diukur menggunakan soil tester dan $\mathrm{pH}$ air menggunakan $\mathrm{pH}$ pen. Salinitas diukur menggunakan refraktometer. Suhu air diukur menggunakan termometer air.

Kerang Donax dibersihkan cangkangnya kemudian diidentifikasi menggunakan buku identifikasi Poutiers (1998), Dharma (2005), serta Ambarwati dan Faizah (2017). Pengukuran morfometri kerang Donax dilakukan dengan menggunakan jangka sorong dengan ketelitian 0,01 mm. Ambarwati dan Faizah (2017) menjelaskan bahwa dimensi cangkang kerang Donax yang dapat diukur meliputi panjang cangkang, tinggi cangkang, lebar cangkang, tinggi dorsal, dan garis tepi umbo. Panjang cangkang didefinisikan sebagai jarak tegak lurus antara anterior dan posterior cangkang. Pengukuran tinggi cangkang dari bagian tertinggi dorsal ke bagian terendah ventral cangkang. Lebar cangkang didefinisikan sebagai jarak antara bagian yang menonjol dari sisi lateral dua cangkang. Pengukuran tinggi dorsal berasal dari bagian yang paling tinggi sisi dorsal ke garis semu dengan jarak tegak lurus antara anterior dan posterior cangkang. Garis tepi umbo didefinisikan sebagai jarak dari bagian paling tinggi dorsal cangkang ke posterior cangkang.

HASIL DAN PEMBAHASAN 
Penelitian yang dilakukan di Pantai Tengket, berdasarkan sampling ditemukan kerang Donax faba berjumlah 544 individu dan terdapat 15 variasi pola dan warna. Ambarwati dan Faizah (2017) melaporkan populasi $D$. cuneatus dan $D$. faba dari Pantai Nepa Sampang Madura, dan mendeskripsikan 12 variasi pola dan warna yang berbeda pada kerang $D$. cuneatus dan D. faba.

Dalam penelitian ini terdapat lima variasi baru D. faba yang belum ditemukan di pantai Nepa, yaitu Tipe 11 (eksterior berwarna putih keunguan dengan bercak cokelat, interior berwarna ungu dengan bagian putih); Tipe 12 (eksterior berwarna ungu dengan bercak cokelat, interior berwarna ungu tua); Tipe 13 (eksterior berwarna putih dengan pita radial cokelat, interior berwarna putih dengan pita radial ungu); Tipe 14 (eksterior berwarna putih dengan pita radial orange, interior berwarna putih dengan pita radial orange; Tipe 15 (eksterior berwarna krem dengan bercak cokelat di bagian ventral, interior berwarna putih bintik kuning dengan ungu di ventral). Umumnya pita radial hanya terdapat pada D. cuneatus, ternyata pita radial juga dapat ditemukan pada $D$. faba. Terdapat dua variasi yang tidak ditemukan di Pantai Tengket, akan tetapi ditemukan di Pantai Nepa yaitu (1) eksterior: putih keunguan, interior ungu dengan bagian putih di garis ventral; dan (2) eksterior: putih dengan bercak cokelat, interior ungu bintik putih di bagian ventral (Ambarwati dan Faizah, 2017). Pada tipe dua memiliki empat perbedaan motif, akan tetapi warna eksterior dan interior tidak jauh berbeda yaitu putih. Penelitian sebelumnya juga melaporkan variasi $D$. cuneatus dan $D$. faba di Singapura (Tan dan Low, 2013).

Smith (1975) menjelaskan bahwa adanya banyak variasi pada satu jenis kerang Donax disebabkan karena intensitas pigmen. Biasanya pigmen lebih kuat di sepanjang garis pertumbuhan. Selain itu, variasi morfologi pada $D$. faba ini juga terkait dengan plastisitas genetik. Soares dkk (1998) melaporkan bahwa plastisitas fenotip merupakan faktor penting dalam perubahan fisik variasi morfologi D. serra. Laudien dkk (2003) juga melaporkan dalam penelitiannya bahwa plastisitas fenotip pada D. serra berpengaruh terhadap perbedaan bentuk cangkang yang disebabkan oleh faktorfaktor lingkungan.

Donax faba yang ditemukan memiliki karakteristik panjang cangkang berkisar antara 13-17 mm, cangkang berbentuk trigonal dilihat dari rasio LC/PC berkisar antara 0,35-040 mm; LC/TC berkisar 0,52-0,55 mm; dan TC/PC 
berkisar 0,67-0,73 mm (Tabel 1). Bagian eksternal cangkang memiliki pola garis konsentris dan kasar. Umbo kecil dan tumpul, serta menghadap ke bagian posterior cangkang. Hasil analisis morfologi menunjukkan bahwa terdapat 15 variasi pola dan warna (Gambar 1$)$.

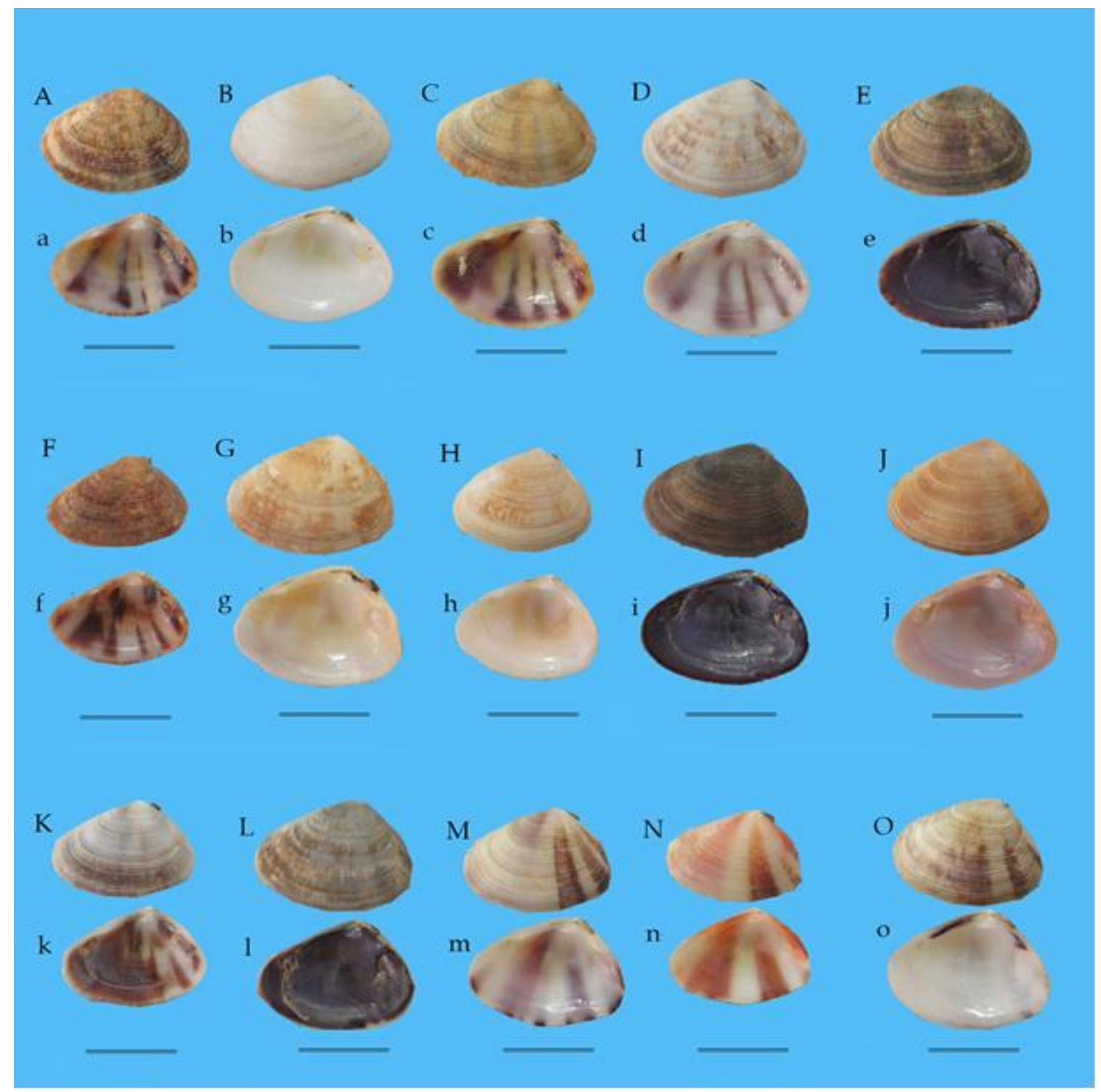

Gambar 1. Variasi morfologi Donax faba dari Pantai Tengket Bangkalan Madura; A,a: Tipe 1; B,b: Tipe 2; C,c: Tipe 3; D,d: Tipe 4; E,e: Tipe 5; F,f: Tipe 6; G,g: Tipe 7; H,h: Tipe 8; I,i; Tipe 9; J,j: 10; K,k: Tipe 11: L,l: Tipe 12; M,m: Tipe 13; N,n: Tipe 14; 0,o: Tipe 15, scale bar: $10 \mathrm{~mm}$ 
Penelitian ini menggunakan analisis morfometri untuk mengetahui morfologi dari berbagai variasi kerang Donax yang ditemukan. Hasil pengukuran morfometri menunjukkan panjang D. faba yang diperoleh di Pantai Tengket sebesar 13$17 \mathrm{~mm}$, tinggi cangkang 6-9 $\mathrm{mm}$, dan lebar cangkang 4-5 mm. Ambarwati dan Faizah (2017) menjelaskan panjang $D$. faba dapat berukuran hingga 26,8 mm. Singh dkk (2011) melaporkan bahwa $D$. faba yang ditemukan di Pantai Panambur India, dapat tumbuh hingga panjang $15,52 \mathrm{~mm} ; 22,09 \mathrm{~mm} ; 24,79 \mathrm{~mm}$ dan
25,90 mm berturut-turut pada tahun pertama, kedua, ketiga, dan keempat. Singh (2017) juga melaporkan bahwa $D$. faba yang ditemukan di Pantai Padukere India, memiliki ukuran panjang mencapai $16,26 \mathrm{~mm}, 22,66 \mathrm{~mm}$, dan $25,30 \mathrm{~mm}$ berturut-turut pada tahun pertama, kedua, dan ketiga. Hal ini menunjukkan bahwa $D$. faba yang ada di Pantai Tengket memiliki ukuran yang lebih kecil dibandingkan dengan yang ditemukan di beberapa pantai lain di penelitian sebelumnya.

Tabel 1 Variasi warna dan morfometri kerang Donax faba di Pantai Tengket Bangkalan Madura

\begin{tabular}{|c|c|c|c|c|c|c|c|c|c|c|}
\hline \multirow[b]{2}{*}{ Tipe } & \multirow[b]{2}{*}{ Warna cangkang } & \multirow[b]{2}{*}{$\mathbf{n}$} & \multirow[b]{2}{*}{$\begin{array}{c}\text { PC } \\
(\mathrm{mm})\end{array}$} & \multirow[b]{2}{*}{$\begin{array}{c}\text { TD } \\
(\mathrm{mm})\end{array}$} & \multirow[b]{2}{*}{$\begin{array}{c}\text { TC } \\
(\mathrm{mm})\end{array}$} & \multirow[b]{2}{*}{$\begin{array}{c}\text { GU } \\
(\mathrm{mm})\end{array}$} & \multirow[b]{2}{*}{$\begin{array}{c}\text { LC } \\
(\mathrm{mm})\end{array}$} & \multicolumn{3}{|c|}{ Ratio } \\
\hline & & & & & & & & $\begin{array}{l}\text { LC/ } \\
\text { PC }\end{array}$ & $\begin{array}{c}\text { LC/ } \\
\text { TC }\end{array}$ & $\begin{array}{l}\text { TC/ } \\
\text { PC }\end{array}$ \\
\hline $\begin{array}{c}\text { Tipe } \\
1\end{array}$ & $\begin{array}{l}\text { Eksterior: cokelat } \\
\text { muda dengan } \\
\text { bercak cokelat; } \\
\text { interior: kuning } \\
\text { bercak ungu }\end{array}$ & 56 & $\begin{array}{c}14,6 \pm \\
2,29\end{array}$ & $\begin{array}{c}7,18 \pm \\
2,14\end{array}$ & $\begin{array}{c}10,18 \pm \\
1,80\end{array}$ & $\begin{array}{c}9,66 \pm \\
1,87\end{array}$ & $\begin{array}{c}5,07 \pm \\
1,01\end{array}$ & 0,35 & 0,50 & 0,70 \\
\hline $\begin{array}{c}\text { Tipe } \\
2\end{array}$ & $\begin{array}{l}\text { Eksterior: putih; } \\
\text { interior: putih } \\
\text { bintik kuning }\end{array}$ & 53 & $\begin{array}{c}15,12 \pm \\
2,95\end{array}$ & $\begin{array}{c}8,08 \pm \\
2,88\end{array}$ & $\begin{array}{c}11,13 \pm \\
3,08\end{array}$ & $\begin{array}{c}10,43 \pm \\
2,88\end{array}$ & $\begin{array}{c}5,25 \pm \\
1,11\end{array}$ & 0,35 & 0,47 & 0,74 \\
\hline $\begin{array}{c}\text { Tipe } \\
3\end{array}$ & $\begin{array}{l}\text { Eksterior: kuning } \\
\text { dengan bercak } \\
\text { cokelat; interior: } \\
\text { ungu dengan bagian } \\
\text { kuning }\end{array}$ & 67 & $\begin{array}{c}16,27 \pm \\
1,83\end{array}$ & $\begin{array}{c}7,82 \pm \\
1,65\end{array}$ & $\begin{array}{c}11,39 \pm \\
1,55\end{array}$ & $\begin{array}{c}10,80 \pm \\
1,60\end{array}$ & $\begin{array}{c}5,81 \pm \\
0,88\end{array}$ & 0,36 & 0,51 & 0,70 \\
\hline $\begin{array}{c}\text { Tipe } \\
4\end{array}$ & $\begin{array}{l}\text { Eksterior: putih } \\
\text { dengan bercak } \\
\text { cokelat; interior: } \\
\text { putih dengan garis } \\
\text { ungu }\end{array}$ & 17 & $\begin{array}{c}16,72 \pm \\
2,01\end{array}$ & $\begin{array}{c}7,08 \pm \\
1,40\end{array}$ & $\begin{array}{c}11,72 \pm \\
1,57\end{array}$ & $\begin{array}{c}10,95 \pm \\
1,38\end{array}$ & $\begin{array}{c}6,34 \pm \\
0,98\end{array}$ & 0,38 & 0,54 & 0,70 \\
\hline $\begin{array}{l}\text { Tipe } \\
5\end{array}$ & $\begin{array}{l}\text { Eksterior: cokelat } \\
\text { keunguan dengan } \\
\text { bercak cokelat; } \\
\text { interior: ungu tua }\end{array}$ & 63 & $\begin{array}{c}16,07 \pm \\
2,07\end{array}$ & $\begin{array}{c}8,46 \pm \\
1,75\end{array}$ & $\begin{array}{c}11,40 \pm \\
1,58\end{array}$ & $\begin{array}{c}10,60 \pm \\
1,67\end{array}$ & $\begin{array}{c}5,92 \pm \\
0,88\end{array}$ & 0,37 & 0,54 & 0,71 \\
\hline $\begin{array}{l}\text { Tipe } \\
6\end{array}$ & $\begin{array}{l}\text { Eksterior: cokelat } \\
\text { dengan bercak } \\
\text { krem; interior: } \\
\text { kuning dengan } \\
\text { garis ungu }\end{array}$ & 10 & $\begin{array}{c}15,10 \pm \\
1,86\end{array}$ & $\begin{array}{c}8,27 \pm \\
1,73\end{array}$ & $\begin{array}{c}10,75 \pm \\
1,88\end{array}$ & $\begin{array}{c}10,61 \pm \\
1,92\end{array}$ & $\begin{array}{c}5,61 \pm \\
0,98\end{array}$ & 0,37 & 0,52 & 0,71 \\
\hline
\end{tabular}


Biotropic 2018 Vol.2 (2): $73-84$

Variasi Morfologi dan Kemelimpahan Kerang Donax (Bivalvia: Donacidae) di Pantai Tengket Bangkalan Madura

\begin{tabular}{|c|c|c|c|c|c|c|c|c|c|c|}
\hline \multirow[b]{2}{*}{ Tipe } & \multirow[b]{2}{*}{ Warna cangkang } & \multirow[b]{2}{*}{$\mathbf{n}$} & \multirow{2}{*}{$\begin{array}{c}\text { PC } \\
(\mathrm{mm})\end{array}$} & \multirow{2}{*}{$\begin{array}{c}\text { TD } \\
(\mathrm{mm})\end{array}$} & \multirow{2}{*}{$\begin{array}{c}\text { TC } \\
(\mathrm{mm})\end{array}$} & \multirow{2}{*}{$\begin{array}{c}\text { GU } \\
(\mathbf{m m})\end{array}$} & \multirow{2}{*}{$\begin{array}{c}\text { LC } \\
(\mathrm{mm})\end{array}$} & \multicolumn{3}{|c|}{ Ratio } \\
\hline & & & & & & & & $\begin{array}{l}\text { LC/ } \\
\text { PC }\end{array}$ & $\begin{array}{c}\text { LC/ } \\
\text { TC }\end{array}$ & $\begin{array}{l}\text { TC/ } \\
\text { PC } \\
\end{array}$ \\
\hline $\begin{array}{c}\text { Tipe } \\
7\end{array}$ & $\begin{array}{l}\text { Eksterior: krem } \\
\text { dengan bercak } \\
\text { cokelat; interior: } \\
\text { krem dengan bintik } \\
\text { kuning }\end{array}$ & 32 & $\begin{array}{c}15,85 \pm \\
2,31\end{array}$ & $\begin{array}{c}8,04 \pm \\
2,14\end{array}$ & $\begin{array}{c}11,08 \pm \\
1,90\end{array}$ & $\begin{array}{c}10,34 \pm \\
1,88\end{array}$ & $\begin{array}{c}5,58 \pm \\
1,10\end{array}$ & 0,35 & 0,50 & 0,70 \\
\hline $\begin{array}{c}\text { Tipe } \\
8\end{array}$ & $\begin{array}{l}\text { Eksterior: krem ke } \\
\text { merah mudaan } \\
\text { dengan bercak } \\
\text { cokelat; interior: } \\
\text { krem ke merah } \\
\text { mudaan }\end{array}$ & 15 & $\begin{array}{c}15,08 \pm \\
3,64\end{array}$ & $\begin{array}{c}8,66 \pm \\
2,46\end{array}$ & $\begin{array}{c}11,01 \pm \\
2,23\end{array}$ & $\begin{array}{c}10,52 \pm \\
2,11\end{array}$ & $\begin{array}{c}5,99 \pm \\
1,03\end{array}$ & 0,39 & 0,54 & 0,73 \\
\hline $\begin{array}{c}\text { Tipe } \\
9\end{array}$ & $\begin{array}{l}\text { Eksterior: cokelat } \\
\text { tua; interior: ungu } \\
\text { tua }\end{array}$ & 9 & $\begin{array}{c}13,66 \pm \\
2,06\end{array}$ & $\begin{array}{c}6,23 \pm \\
1,51\end{array}$ & $\begin{array}{c}9,10 \pm \\
1,71\end{array}$ & $\begin{array}{c}8,96 \pm \\
1,63\end{array}$ & $\begin{array}{c}4,92 \pm \\
0,92\end{array}$ & 0,36 & 0,54 & 0,67 \\
\hline $\begin{array}{c}\text { Tipe } \\
10\end{array}$ & $\begin{array}{l}\text { Eksterior: cokelat } \\
\text { muda; interior: } \\
\text { ungu muda }\end{array}$ & 13 & $\begin{array}{c}15,64 \pm \\
3,08\end{array}$ & $\begin{array}{c}7,80 \pm \\
2,60\end{array}$ & $\begin{array}{c}10,93 \pm \\
2,54\end{array}$ & $\begin{array}{c}10,36 \pm \\
2,69\end{array}$ & $\begin{array}{c}5,85 \pm \\
1,55\end{array}$ & 0,37 & 0,54 & 0,70 \\
\hline $\begin{array}{c}\text { Tipe } \\
11\end{array}$ & $\begin{array}{l}\text { Eksterior: putih } \\
\text { keunguan dengan } \\
\text { bercak cokelat; } \\
\text { interior: ungu } \\
\text { dengan bagian } \\
\text { putih }\end{array}$ & 6 & $\begin{array}{c}17,1 \pm \\
1,13\end{array}$ & $\begin{array}{c}9,42 \pm \\
1,24\end{array}$ & $\begin{array}{c}12,25 \pm \\
0,57\end{array}$ & $\begin{array}{c}11,75 \pm \\
0,83\end{array}$ & $\begin{array}{c}6,83 \pm \\
0,70\end{array}$ & 0,40 & 0,56 & 0,72 \\
\hline $\begin{array}{c}\text { Tipe } \\
12\end{array}$ & $\begin{array}{l}\text { Eksterior: ungu } \\
\text { dengan bercak } \\
\text { cokelat; interior: } \\
\text { ungu tua }\end{array}$ & 9 & $\begin{array}{c}15,05 \pm \\
2,63\end{array}$ & $\begin{array}{c}8,10 \pm \\
2,22\end{array}$ & $\begin{array}{c}10,02 \pm \\
2,16\end{array}$ & $\begin{array}{c}9,93 \pm \\
2,23\end{array}$ & $\begin{array}{c}5,51 \pm \\
1,21\end{array}$ & 0,37 & 0,55 & 0,67 \\
\hline $\begin{array}{c}\text { Tipe } \\
13\end{array}$ & $\begin{array}{l}\text { Eksterior: putih } \\
\text { dengan pita radial } \\
\text { cokelat; interior: } \\
\text { putih dengan pita } \\
\text { radial ungu }\end{array}$ & 10 & $\begin{array}{c}15,67 \pm \\
1,60\end{array}$ & $\begin{array}{c}8,04 \pm \\
0,89\end{array}$ & $\begin{array}{c}11,09 \pm \\
1,57\end{array}$ & $\begin{array}{c}10,29 \pm \\
1,14\end{array}$ & $\begin{array}{c}5,95 \pm \\
1,04\end{array}$ & 0,38 & 0,54 & 0,71 \\
\hline $\begin{array}{c}\text { Tipe } \\
14\end{array}$ & $\begin{array}{l}\text { Eksterior: putih } \\
\text { dengan pita radial } \\
\text { orange; interior: } \\
\text { putih dengan pita } \\
\text { radial orange }\end{array}$ & 9 & $\begin{array}{c}14,60 \pm \\
2,79\end{array}$ & $\begin{array}{c}8,18 \pm \\
2,14\end{array}$ & $\begin{array}{c}10,36 \pm \\
2,10\end{array}$ & $\begin{array}{c}9,65 \pm \\
2,34\end{array}$ & $\begin{array}{c}5,45 \pm \\
0,98\end{array}$ & 0,37 & 0,53 & 0,71 \\
\hline $\begin{array}{l}\text { Tipe } \\
15\end{array}$ & $\begin{array}{l}\text { Eksterior: krem } \\
\text { dengan bercak } \\
\text { cokelat bagian } \\
\text { ventral; interior: } \\
\text { putih bintik kuning } \\
\text { dengan ungu di } \\
\text { ventral }\end{array}$ & 175 & $\begin{array}{c}15,37 \pm \\
2,51\end{array}$ & $\begin{array}{c}6,48 \pm \\
2,11\end{array}$ & $\begin{array}{c}10,61 \pm \\
2,05\end{array}$ & $\begin{array}{c}10,01 \pm \\
2,00\end{array}$ & $\begin{array}{c}5,47 \pm \\
1,20\end{array}$ & 0,36 & 0,52 & 0,69 \\
\hline
\end{tabular}

Keterangan:

PC : Panjang cangkang

TD: Tinggi dorsal
TC: Tinggi cangkang

GU: Garis tepi umbo
LC: Lebar cangkang

$\mathrm{n}$ : Jumlah sampel
Zeichen dkk (2002) melaporkan Populasi D. trunculus diketahui memiliki panjang maksimum $37 \mathrm{~mm}$ dan panjang usia empat tahun. Ukuran panjang individu D. trunculus yang berkisar mulai dari 3-9 mm lebih berlimpah di perairan dangkal, sedangkan individu terbesar yaitu ukuran 25-37 mm berada di bawah 
kedalaman $0,7 \mathrm{~m}$. Penelitian Jerardino dkk (2014) menunjukkan bahwa D. serra memiliki distribusi ukuran morfometri yang berbeda. Karakteristik morfometri tipe $D$. faba bervariasi, namun umumnya memiliki bentuk baji (Ambarwati dan Faizah, 2017). Hal ini dapat ditunjukkan oleh rasio LC/PC berkisar antara 0,350,40, LC/TC berkisar 0,52-0,55, dan TC/PC berkisar 0,67-0,73.

Kemelimpahan populasi Donax berada di daerah intertidal pantai berpasir (Dugan dan McLachlan, 1999). Berbagai variasi $D$. faba memiliki nilai kemelimpahan yang berbeda, kemelimpahan relatif tertinggi diperoleh tipe 15 yaitu krem dengan bercak cokelat di bagian ventral sebesar $32,17 \%$ dan nilai kemelimpahan terendah diperoleh tipe 11 yaitu putih keunguan dengan bercak cokelat sebesar 1,10\%. Smith (1975) melaporkan bahwa faktor visual berperan penting dalam proses pencarian makan predator, sehingga warna dari cangkang sangat memengaruhi. Kepiting mengonsumsi atau memilih cangkang $D$. faba berwarna putih dibandingkan warna lainnya. Warna krem merupakan warna yang hampir sama dan menyerupai substrat pasir yang ada di Pantai Tengket, hal ini juga berpengaruh terhadap banyaknya $D$. faba yang berwarna krem di Pantai Tengket (Gambar 2).

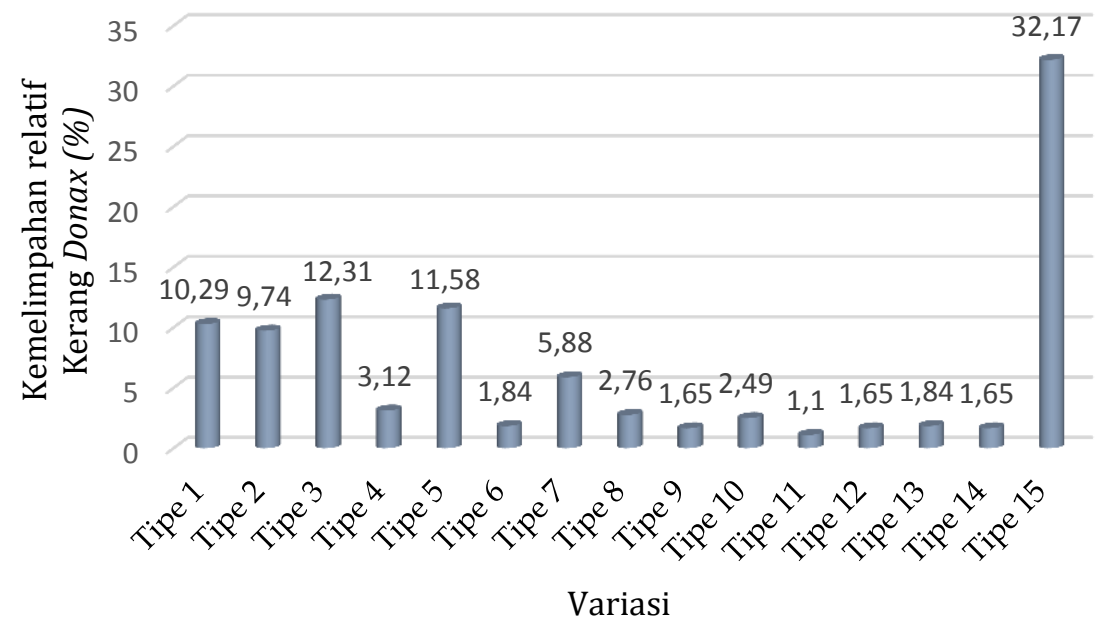

Gambar 2. Kemelimpahan relatif Donax faba di Pantai Tengket Bangkalan Madura

Diketahui terdapat empat variasi bercak cokelat sebesar 10,29\%, tipe dua yang memiliki kemelimpahan cukup berwarna putih sebesar 9,74\%, tipe tiga besar dibandingkan variasi lainnya yaitu berwarna kuning dengan bercak cokelat tipe satu berwarna cokelat muda dengan sebesar $12,31 \%$, dan tipe lima berwarna 
cokelat keunguan dengan bercak cokelat sebesar 11,58\%. Variasi tersebut umumnya memiliki warna yang sama dan menyerupai warna pasir di Pantai Tengket. Selain itu, hal ini dikarenakan variasi tersebut cocok dengan profil habitat yang ada di Pantai Tengket. Begon dkk (1990); Herrmann dkk (2009); Singh menjelaskan bahwa kemelimpahan dipengaruhi oleh faktor habitat kerang serta adanya faktor lingkungan yang penting dalam menentukan distribusi kerang Donax di pantai berpasir, misalnya warna pasir pantai yang menyerupai warna cangkang, kondisi pasir, gerakan gelombang, suhu, dan pasang surut.

Selain adanya perbedaan kemelimpahan berbagai variasi $D$. $f a b a$, juga diketahui bahwa setiap transek pengambilan sampel juga memiliki kemelimpahan D. faba yang berbeda (Gambar 3).

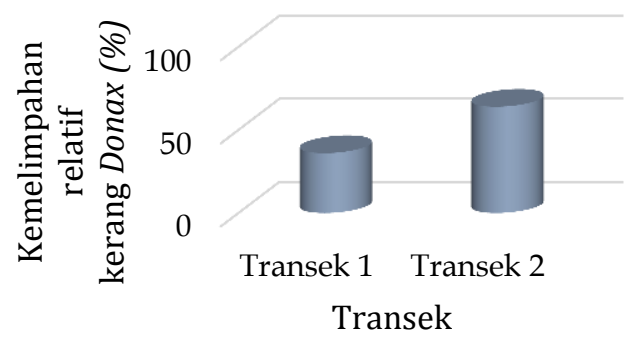

Gambar 3. Kemelimpahan relatif setiap transek pengambilan kerang Donax faba di Pantai Tengket Bangkalan Madura

Nilai kemelimpahan relatif tertinggi yaitu pada transek dua sebesar $63,97 \%$ dan kemelimpahan relatif terendah pada transek satu sebesar 32,03\%. Hal ini disebabkan karena daerah transek satu lebih jarang terkena gerakan pasang surut air laut dibandingkan transek dua. Pada transek dua merupakan daerah yang lebih sering dilewati pasang surut air, akibatnya transek ini memiliki tekstur pasir yang tidak padat serta pasir lebih lembap sehingga pada transek dua merupakan daerah yang lebih optimal untuk kelangsungan hidup $D$. faba. Herrmann dkk (2009) menjelaskan bahwa perbedaan kemelimpahan $D$. hanleyanus secara signifikan terkait dengan tekstur pasir, yaitu semakin padat pasir, maka kerang tersebut akan lebih sulit untuk menggali dan akibatnya kerang tersebut akan hanyut. Kemelimpahan D. hanleyanus tidak dipengaruhi oleh suhu permukaan laut, namun penurunan $D$. hanleyanus di Pantai Utara Argentina disebabkan oleh aktivitas manusia.

Jenis substrat sangat penting dalam perkembangan hewan yang berhabitat di pesisir pantai, substrat pasir memudahkan kerang dalam bergerak dan berpindah tempat (Lindawaty, 2016). Pada penelitian ini, diketahui ukuran butir pasir di Pantai Tengket adalah 0,500 $\mathrm{mm}$, yang tergolong dalam pasir sedang. Distribusi populasi $D$. trunculus sangat 
dipengaruhi oleh variasi ukuran butir sedimen. Ukuran butir yang sesuai memungkinkan untuk tempat tinggal dan pertumbuhan berikutnya dari populasi yang terstruktur dengan baik (Valle dkk, 2011).

Tabel 2. Profil habitat kerang Donax faba di Pantai Tengket Bangkalan Madura

\begin{tabular}{clcc}
\hline \multirow{2}{*}{ No } & \multirow{2}{*}{ Parameter } & \multicolumn{2}{c}{ Data Kimia dan Fisika } \\
\cline { 3 - 4 } & & Transek 1 & Transek 2 \\
\hline 1 & Tipe substrat & \multicolumn{2}{c}{ Pasir sedang } \\
2 & pH air & $6,77 \pm 0,03$ & $6,76 \pm 0,07$ \\
3 & pH substrat & $7 \pm 0$ & $7 \pm 0$ \\
4 & Salinitas $(\% 0)$ & $32,63 \pm 0,76$ & $32,8 \pm 0,88$ \\
5 & Suhu $\left({ }^{\circ} \mathrm{C}\right)$ & $32 \pm 0$ & $32 \pm 0$ \\
\hline
\end{tabular}

Pantai subtropis menunjukkan pertumbuhan yang lebih tinggi dan tingkat kematian rendah daripada pantai beriklim sedang (Herrmann dkk, 2009). Suhu perairan Pantai Tengket pada dua transek konstan bernilai $32^{\circ} \mathrm{C}$ (Tabel 2). Singh dkk ( 2011) melaporkan bahwa $D$. faba di Pantai Panambur India ditemukan pada suhu habitat rata-rata $29^{\circ} \mathrm{C}$. Nilai $\mathrm{pH}$ air di Pantai Tengket adalah 6,7 dan nilai pH substrat 7. Nilai derajat keasaman $(\mathrm{pH})$ air normal yang memenuhi syarat untuk kehidupan organisme berkisar antara 6,5-7,5 (Hardianti dkk, 2014). Nilai salinitas di Pantai Tengket berkisar 32,632,8\% . Air laut umumnya memiliki konsentrasi garam 35\%o, salinitas permukaan air laut berkisar 33-37\%o (Davis, 1990). Hardianti dkk (2014) menjelaskan di perairan pantai biasanya memiliki nilai salinitas lebih rendah dikarenakan adanya pengenceran dari aliran sungai ke laut, sehingga kisaran salinitas adalah 5-35\%o, kisaran tersebut sudah merupakan kondisi optimal bagi kelangsungan hidup kerang.

\section{KESIMPULAN}

Hasil penelitian menunjukkan bahwa Kerang Donax yang ditemukan di Pantai Tengket merupakan Donax faba. D. faba di Pantai Tengket memiliki 15 variasi pola dan warna. Nilai kemelimpahan relatif tertinggi adalah pada tipe 15 yaitu krem dengan bercak cokelat di bagian ventral dan nilai kemelimpahan terendah diperoleh tipe 11 yaitu putih keunguan dengan bercak cokelat. Profil habitat kerang Donax di Pantai Tengket adalah substrat tipe pasir sedang dan $\mathrm{pH}$ substrat 7 , air dengan $\mathrm{pH}$ 6,7, salinitas 32,6-32,8\%o, serta suhu $32^{\circ} \mathrm{C}$.

\section{DAFTAR PUSTAKA}

Ambarwati R, dan Faizah U, 2017. Colour and Morphometric Variation of Donacid Bivalves from Nepa Beach, Madura Island, Indonesia. Biosaintifika: Journal of Biology \& Biology Education, 9 (3): 466-473.

Begon MJL, Harper dan Towsend TR, 1990. Ecology: Individual, Populations and Communities, $2^{\text {nd }}$. USA: Blackwell Scientific Publications. 
Davis RA, 1990. Oceaonography An Introduction To The Marine Environment. USA: University of South Florida.

Dharma B, 2005. Recent and Fossil Indonesian Shells. Hackenheim: Conchbooks.

Dugan JE, dan McLachlan A, 1999. An assessment of longshore movement in Donax serra Roding (Bivalvia: Donacidae) on an exposed sandy beach. Journal of Experimental Marine Biology and Ecology. 234: 111-124.

Hardianti MN, Yunasfi, Desrita, 2014. Bivalvia di Perairan Pantai Cermin, Kabupaten Serdang Bedagai. Manajemen Sumberdaya Perairan. Sumatera Utara: Fakultas Pertanian, Universitas Sumatera Utara.

Herrmann M, Carstensen D, Fischer S, Laudien J, Penchaszadesh PE, Arntz WE, 2009. Population Structure, Growth, and Production of the Wedge Clam Donax hanleyanus (Bivalvia: Donacidae) from Nothern Argentinean Beaches. Journal of shellfish Research. 28 (3): 511-526.

Jerardino A, Navarro RA, Galimberti M, 2014. Changing Collection Strategis of the Clam Donax serra Roding (Bivalvia: Donacidae) during the Pleistocene at Pinnacle Point, South Africa. Journal of Human Evolution. 68: 58-67.

Laudien J, Flint NS, Bank FH, Brey T, 2003. Genetic Morphological Variation in Four Populations of the surf clam Donax serra (Roding) from Southern African Sandy Beaches. Biochemical Systematics and Ecology. 31: 751-772.
Lindawaty, Dewiyanti I, Karina S, 2016. Distribusi dan Kepadatan Kerang Darah (Anadara sp.) berdasarkan Tekstur Substrat di Perairan Ulee Lheue Banda Aceh. Jurnal Ilmiah Mahasiswa Kelautan dan Perikanan Unsyiah. 1 (1): 114-123.

Poutiers JM, 1998. Bivalves. In: FAO Spesies Identification Guide for Fishery Purposes; The Living Marine Resources of The Wertern Central Pasific Volume 1. Rome: FAO.

Singh TY, 2017. Population dynamics of Donax faba (Family: Donacidae) in the coastal waters of Padukere, Karnataka (India). Iranian Journal of Fisheries Science. 16 (1): 411421.

Singh YT, Krishnamoorthy $M$, and Thippeswamy S, 2011. Population Ecology of the Wedge Clam Donax faba (Gmelin) from the Panambur Beach, Near Mangalore, South West Coast of India. Journal of Theoretical and Experimental Biology. 7 (4): 171-182.

Smith DAS, 1975. Polymorphism and Selective Predation in Donax faba Gmelin (Bivalvia: Tellinacea). J. exp. marine Biology Ecology. 17 : 205-219.

Soares AG, Callahan RK, dan Ruyck AMCD, 1998. Microevolution and Phenotypic Plasticity in Donax serra Roding (Bivalvia: Donacidae) on High Energy Sandy Beaches. The Malacological Society of London. 64: 407-421.

Subono AA, Purnomo T, Ambarwati R, 2016. Struktur Populasi Kepiting Tentara (Mictyris longicarpus) di Pantai Pangpajung, Modung, 
Bangkalan, Madura. LenteraBio. 5 (1): 7-13.

Tan SK, \& Low MEY, 2013. Singapore Mollusca : 3. the Family Donacidae (Bivalvia : Veneroida: Tellinoidea). Nature In Singapore, (November), 257-263.

Tan SK, \& Woo HPM, 2010. A Preliminary Checklist of the Molluscs of Singapore. Singapore: Raffles Museum of Biodiversity Research National University of Singapore.
Valle PL, Nicoletti L, Finoia MG, Ardizzone GD, 2011. Donax trunculus (Bivalvia: Donacidae) as a potential biological indicator of grain size variations in beach sediment. Ecological Indicators. 11: 1426-1436.

Zeichen MM, Agnesi S, Mariani A, Maccaroni A, and Ardizzone GD, 2002. Biology and Population Dynamics of Donax trunculus L. (Bivalvia: Donacidae) in the South Adriatic Coast (Italy). Estuarine, Coastal and Self Science. 10 (54): 971-982. 